\title{
ERRATUM
}

\section{Erratum: New native South American Y chromosome lineages}

Marilza S Jota, Daniela R Lacerda, José R Sandoval, Pedro Paulo R Vieira, Dominique Ohasi, José E Santos-Júnior, Oscar Acosta, Cinthia Cuellar, Susana Revollo, Cesar Paz-y-Miño, Ricardo Fujita, Gustavo A Vallejo, Theodore G Schurr, Eduardo M Tarazona-Santos, Sergio DJ Pena, Qasim Ayub, Chris Tyler-Smith, Fabrício R Santos and The Genographic Consortium

Journal of Human Genetics (2016) 61, 675; doi:10.1038/jhg.2016.43

Correction to: Journal of Human Genetics (2016) 61, 593-603; doi:10.1038/jhg.2016.26; published online 31 March 2016

After online publication of this article, an error was identified in the list of authors.
This error has been rectified and the corrected article appears in this issue. The html and online pdf versions have also been rectified.

The publishers apologize for any inconvenience caused and are happy to correct this error. 